\title{
A note on the silent GO that underlies an instance of apparent suppletion in Spanish
}

\author{
Richard S. Kayne \\ University of New York (NYU) \\ richard.kayne@nyu.edu
}

Received: $24-07-2020$

Accepted: $18-09-2020$

Published: 28-09-2020

How to cite: Kayne, Richard. 2020. A note on the silent GO that underlies an instance of apparent suppletion in Spanish. Isogloss. Open Journal of Romance Linguistics 6/4. DOI: https://doi.org/10.5565/rev/isogloss.94

\begin{abstract}
The Spanish counterpart of English go shows apparently suppletive forms as follows. The alternation between $\mathrm{v}-$, f- and $\mathrm{i}$ - seems not to be phonological. We can call it 'suppletion' as long as we recognize that doing so leaves questions open that we need to try to answer. In this paper, I will focus on the forms in $\mathrm{f}$-. A familiar way of talking about the f- in question would be to say that it is inserted (late) as a realization of Spanish go in the context of preterite or imperfect subjunctive (or of what the preterite and the imperfect subjunctive have in common). I will, instead, try to throw some light on the identity of preterite and imperfect subjunctive forms across Spanish go and be by bringing in additional considerations that have nothing directly to do with verb morphology.
\end{abstract}

Keywords: suppletion; subjunctive; Spanish; morphology; syntax 


\section{Table of Contents}

\section{Introduction}

2. How not to proceed

3. How to proceed. Silent GO

4. Back to Spanish

5. Challenges, as usual

6. Back to Spanish, again

\author{
7. Further challenges \\ 8. Further support; other instances of \\ GO \\ 9. Acquisition \\ 10. Conclusion \\ References
}

\section{Introduction}

The Spanish counterpart of English go shows apparently suppletive forms as follows. Present tense forms have an initial $v$-in both indicative:

$$
\begin{array}{llllll}
\text { voy, } & \text { vas, } & \text { va, } & \text { vamos, } & \text { vais, } & \text { van } \\
\text { go-1.SG } & \text { go-2.SG } & \text { go-3.SG } & \text { go-1.PL } & \text { go-2.PL } & \text { go-3.PL }
\end{array}
$$

and subjunctive:

$$
\begin{aligned}
& \text { vaya, vayas, vaya, vayamos, vayáis, vayan }{ }^{1} \\
& \text { go-1.SG go-2.SG go-3.SG go-1.PL go-2.PL go-3.PL }
\end{aligned}
$$

The preterite and the imperfect subjunctive forms, on the other hand, have an initial $f-$; in the preterite, the forms are:

$$
\begin{aligned}
& \text { fui, fuiste, fue, fuimos, fuisteis, fueron } \\
& \text { go-1.SG go-2.SG go-3.SG go-1.PL go-2.PL go-3.PL }
\end{aligned}
$$

and in the imperfect subjunctive:

(4) fuera, fueras, fuera, fuéramos, fuerais, fueran ${ }^{2}$ go-1.SG go-2.SG go-3.SG go-1.PL go-2.PL go-3.PL

In addition, there are forms of Spanish go with initial $i$-. The infinitive, for example, is $i r$, the past participle -ido, and the imperfect indicative has the forms:

$$
\begin{array}{llllll}
\text { iba, } & \text { ibas, } & \text { iba, } & \text { íbamos, } & \text { ibais, } & \text { iban } \\
\text { go-1.SG } & \text { go-2.SG } & \text { go-3.SG } & \text { go-1.PL } & \text { go-2.PL } & \text { go-3.PL }
\end{array}
$$

Furthermore, the future and conditional, which are arguably built on the infinitive, ${ }^{3}$ have the $i$-initial forms:

1 Many varieties of Spanish lack 2pl. forms, in a way that is not relevant to the present paper.

2 There is also a(n obsolete - Roca $(2010,409,422 \mathrm{n}))$ future subjunctive with initial $f$-, as well as an alternative set of imperfect subjunctive forms with -se- in place of $-r a$.

3 Cf. Harris $(1969,92$.$) ; also Pollock (2006,651)$ on French. 
(6)

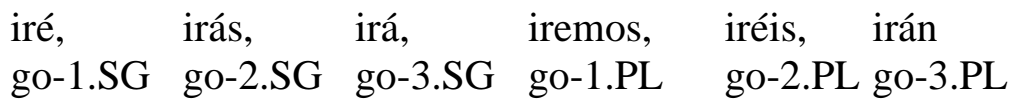

and:

$$
\begin{aligned}
& \text { iría, irías, iría, iríamos, iríais, irían } \\
& \text { go-1.SG go-2.SG go-3.SG go-1.PL go-2.PL go-3.PL }
\end{aligned}
$$

respectively.

The alternation between $v$-, $f$ - and $i$ - seems not to be phonological. We can call it suppletion, ${ }^{4}$ as long as we recognize that doing so leaves questions open that we need to try to answer.

\section{How not to proceed}

In this paper, I will focus on the forms in $f$-.

A familiar way of talking about the $\mathrm{f}$ - in question would be to say that it is inserted (late) as a realization of Spanish go in the context of preterite or imperfect subjunctive (or of what the preterite and the imperfect subjunctive have in common).

This would at first glance 'get the facts', though not in an ambitious way. In addition, it would miss the generalization that the $f$-initial forms for Spanish $g o$ are identical to the preterite and imperfect subjunctive forms of Spanish ser ('be'). ${ }^{5}$ (Nor, it seems to me, would there be much insight to be gained by stating that Spanish go and be are syncretic in the preterite and in the imperfect subjunctive.)

\section{How to proceed. Silent GO}

I will, instead, try to throw some light on the identity of preterite and imperfect subjunctive forms across Spanish go and be by bringing in additional considerations that have nothing directly to do with verb morphology. ${ }^{6}$ Let me begin with English and in particular with English sentences such as:

(8) Have they been to Paris yet?

$4 \quad$ Cf. Harris $(1969,92)$; also Stockwell, Bowen and Martin $(1965,116)$, as well as Pensado (1999, 4433n).

$5 \quad$ Spanish has another verb estar that also in some cases translates English be (estar is not relevant to the present discussion, as far as I can see). For recent discussion of ser vs. estar, cf. Gallego and Uriagereka (2016), whose analysis may be a problem for Myler (2018).

6 To a large extent, the proposed analysis will carry over to Portuguese $f$-initial forms of $g o$. 
which contains a directional PP to Paris in the context of usually non-directional $b e$. That be often rejects directional PPs is seen, for example, in: ${ }^{7}$

(9) *The books are to the bookshelves.

The obvious proposal is that (8) contains a verb that is compatible with directional PPs, the simplest such verb presumably being go. This yields, for (8):

(10) have they been GO to Paris yet?

in which the capitalized GO indicates a silent counterpart of overt $g o$.

The existence of (10) and structures like it will in fact automatically be imposed by the language faculty if we adopt a key proposal by Collins $(2007,24)$, namely:

(11) A directional PP is always the complement of the verb "go", which may be covert in certain cases.

Given Collins's proposal in (11), the presence of directional to Paris in (8) forces (8) to contain GO.

\section{Back to Spanish}

Let us now take a Spanish sentence with what looks like an $f$-initial form of $g o$, e.g.:

$$
\begin{aligned}
& \text { Fuimos a casa } \\
& \text { go-3.PST.PL to home } \\
& \text { 'Fuimos to home' }
\end{aligned}
$$

Given (10), the following analysis comes to the fore. The form fuimos in (12) is not a form of go at all, but rather a form of be (ser) that, in (12), is accompanied by silent GO:

$$
\begin{aligned}
& \text { fuimos GO a casa } \\
& \text { go-3.PST.PL GO to home } \\
& \text { 'we-were GO to home' (= 'we went home') }
\end{aligned}
$$

It is this GO that licenses the directional PP a casa.

If so, the form fuimos is in every case in Spanish a form of ser ('be'). It is never itself a form of $i r$ ('go'); rather, Spanish allows such forms of ser to cooccur with silent GO.

7 This point was made for Slovenian by Marušič \& Žaucer (2005), in the course of strongly arguing for instances of a silent GO in that language. 
Consequently, to speak of fuimos as a suppletive form of Spanish ir ('go') would be misleading (and similarly for all the $f$-initial forms under consideration). Suppletion in the familiar sense of the term is not in the end appropriate for the $f$ initial forms in sentences like (12), if the present proposal based on silent GO is on the right track.

\section{Challenges, as usual}

English (10) and Spanish (13) have in common the presence of GO. Yet the corresponding sentences differ interpretively, in that while Spanish (12) can have the interpretation of We went home, English (8) is not interpretively equivalent to:

(14) Have they gone to Paris yet?

The difference can be brought out by pairs such as:

(15) The sailors have gone to sea.

(16) The sailors have been to sea.

in which been seems to suggest that the sailors have come back. ${ }^{8}$ Probably related to this is the following contrast:

(17) They've gone from New York to Boston twice this year.

(18) *?They've been from New York to Boston twice this year.

This interpretive difference is not surprising per se. Sentences (15) and (17) contain one verb gone, but (16) and (18) each contain two verbs, been and GO. The challenge is to understand why this particular interpretive difference holds. There may be a link to Charnavel's (2008) discussion of the French 'passé surcomposé' ('hypercomposite past tense'), an example of which is:
Il a
eu fumé.
He have-3.SG had smoked
'He has had smoked'

with one finite auxiliary and two (active) past participles, the first of which is also an auxiliary. ${ }^{9}$ According to Charnavel (note 2), the interpretation of (19) is essentially that of:

8 Cf. Huddleston $(2002,145)$ and Mittwoch, Huddleston and Collins $(2002,685)$.

9 Two active past participles in a row, with the first a participle of have, is something also found in Faroese; cf. Lockwood (1977, 141ff.). Similarly, Harris $(1993,159)$ gives, for some Irish English:

(i) I shoulda haven killed him 
(20)

Il fumait et il ne fume plus.

He smoke-IPFV-3.SG and he NEG smoke-3.SG no-longer

'He used to smoke and he does not smoke anymore'

with the 'no longer' component of the interpretation of (19) now seen to recall the 'come back' component of the interpretation of (16).

The discussion so far has taken (16) to contain been and GO. The common point between (16) and (19) suggests a slight revision. Instead of GO, (16) may contain the (active) past participle GONE:

(21) the sailors have been GONE to sea

and the same for (10), repeated here:

(22) have they been GO to Paris yet?

which is now to be understood as:

(23) have they been GONE to Paris yet?

In a way that will need to be spelled out further, the two active past participles in English (21) and (23) and in French (19) combine to provide the "no longer'/'(come) back' aspect of interpretation. ${ }^{10}$

\section{Back to Spanish, again}

This necessary 'no longer'/'(come) back' aspect of interpretation of (19), (21) and (23) does not, as far as I know, hold of Spanish (13). Possibly, this is due to Spanish (13), repeated here:

$$
\begin{aligned}
& \text { fuimos } \quad \text { GO a casa } \\
& \text { go-3.PST.PL GO to home } \\
& \text { 'we-were GO to home' (= 'we went home') }
\end{aligned}
$$

containing GO (as indicated) rather than GONE. If so, one will need to ask what exactly leads the learner of English to posit GONE rather than GO (and the learner of Spanish to posit GO rather than GONE).

A further interpretive question arises concerning the combination of 'be' and 'go' in (25). On the face of it, it appears that 'be'/fuimos in (25) makes no interpretive contribution. If so, we would want to relate that to the more general question of what interpretive contribution 'be' (especially auxiliary 'be') makes in general, cross-linguistically, ${ }^{11}$ as well as to the question of when non-contributing 'be' is allowed to appear.

10 For relevant discussion of tense and aspect, cf. Giorgi and Pianesi (1997).

11 For relevant discussion, see Baker (2003). 
Spanish allows silent GO in the presence of a(n uninterpreted) form of be only when the form of $b e$ is $f$-initial. If the form of $b e$ is $s$-initial or $e$-initial, the go-interpretation is not available, as in, for example:

$$
\begin{aligned}
& \text { Soy... } \\
& \text { be-1.SG } \\
& \text { 'I-am...' }
\end{aligned}
$$

(27) Eran...

be-3.PL

'they-were...'

Let me suggest that the generalization is not to be formulated directly in terms of the initial segment of the verb form. Instead, we should look in the direction of tense and/or aspect. The reason is that there is an intriguing parallelism here between Spanish and English.

Consider again an example akin to (8):

(28) They've been to Paris twice this year.

English allows a go-like-interpretation in this sentence, but not in any of the following:

(29) *They'll be to Paris next year.

(30) *They hope to be to Paris next year.

(31) *They're being to Paris next week.

(32) *They were often to Paris in their youth.

Huddleston $(2002,114)$ takes the generalization to be that instances of what he calls 'motional' be (which from the present perspective contain silent GO) occur only with have followed by the past participle, as in (28).

My impression, though, is that in some varieties of English it is also possible to have:

(33) They were to Paris twice last year.

The varieties of English in question are likely to be the same as those mentioned by Mittwoch, Huddleston and Collins $(2002,713)$ that allow the following:

Did they leave yet? 
As a first approximation, let us say that a necessary condition for sentences such as (28) and (33) in English is past tense, perhaps necessarily of a perfective sort, given the impossibility of:

*They were being to Paris when I last saw them.

*They used to be to Paris a lot.

Taking this to be on the right track, we can now see that there is a point of similarity with the Spanish contrast between the well-formed preterite (25) and the ill-formed (in the 'go'-interpretation) non-preterite (26)/(27).

Both in English and in Spanish, some notion (to be made precise) of preterite/past/perfect constitutes a necessary condition for these $b e+\mathrm{GO}(\mathrm{NE})$ sentences. ${ }^{12}$ (Future work will also need to make precise exacty how the Spanish imperfect subjunctive, whose $f$-initial forms are also compatible with $\mathrm{GO}$, fits in. $\left.{ }^{13}\right)$. To the extent that Spanish $(25) /(26) /(27)$ shares this significant tense/aspect property with English sentences that contain GO(NE), as in (28) and (33), the attribution of silent GO to Spanish (25) (and with it the importance of silent verbs to traditional questions of morphology) is strengthened.

\section{Further challenges}

The proposal I have been developing eliminates an instance of apparent suppletion in the Spanish counterpart of $g o$ by taking the relevant sentences to contain, rather than an irregular/suppletive form of go, a form of be that is accompanied by a silent GO. In effect, I have taken the $f$-initial forms that appear to be suppletive both in the paradigm for Spanish go (ir) and in the paradigm for Spanish be (ser) to belong entirely to the paradigm for be (ser). (Left for future work is the apparently suppletive paradigm of Spanish (and English) be itself. ${ }^{14}$ )

Also left for future work is the question why, in the relevant Spanish sentences like (25), go must be silent, and similarly for English (28), which is not possible with overt $g o:{ }^{15}$

*They've been go(ne) to Paris twice this year.

12 With the interesting twist that off licenses GO in:

(i) We're *(off) to Paris.

13 Harris $(1969,77)$ notes that the imperfect subjunctive is also called past subjunctive; he tentatively takes it to be imperfective in aspect. As a reviewer notes, the Portuguese future subjunctive will also need to be fit in.

14 Cf. Postma (1993).

15 To what extent, if any, the been here has something significant in common with what Wolfram $(2004,120)$ calls the 'remote (stressed) been' of AAVE remains to be determined. 
At the same time, one needs to allow for Huddleston, Payne and Peterson's $(2002,1303)$ colloquial example $(24)$, repeated here:

(38) He's been and gone and told the teacher.

Possibly, overt go in English forces the pronunciation of an and, as in (38), that is present, though silent, in (28), too.

\section{Further support; other instances of GO}

The plausibility of Spanish having GO in (25) is enhanced, not only by the English examples with GO so far discussed, but also by other instances of GO, in English and in other languages. For example, Kayne (2019a) suggested for English sentences such as They went home the analysis shown in:

\section{they went GO home}

The proposal in (39) rested in part on Collins (2007) and in part on van Riemsdijk's (2002) sustained argument for the presence of silent GO in certain contexts in Swiss German and other non-English Germanic languages. (For some other proposals favoring silent GO in (non-English) Germanic, cf. vanden Wyngaerd $(1994,66)$ (vs. Barbiers $(1995,150)$ ), van Riemsdijk (2003), Noonan (2010), den Dikken (2010), and Bergstra (2019); for GO in Slavic languages, cf. McShane (2000, sect. 3) and Marušič \& Žaucer (2005).)

\section{Acquisition}

With silent GO made available by the language faculty, the learner of Spanish will have available the analysis suggested in this paper. There remains the question why the learner chooses the silent-GO-based analysis over one in which the $f$-initial forms would be taken to be suppletive forms of Spanish ir ('go'), in addition to otherwise existing as forms of ser ('be'). The ideal answer is that the learnability choice doesn't arise in the first place, insofar as this sort of suppletion analysis is not available to the learner, i.e. not countenanced by the language faculty. As for why a suppletion analysis of this sort would be unavailable, it might be, in the spirit of Embick $(2003,156)$ and Kayne $(2017 ; 2019 b)$ that the language faculty strongly frowns on accidental homophony (within the functional subpart of the lexicon), in such a way that the learner of Spanish is prohibited from taking the f-initial forms in question to simultaneously be forms of ser and forms of $i r$.

The final question (for this paper) is why the learner of Spanish takes these $f$-initial forms to be forms of ser rather than forms of $i r$. The answer must be of the following type. A sentence interpreted as a sentence of 
'going' can have overt (uninterpretable) 'be' accompanying GO. Whereas a sentence interpreted as a sentence of 'being' could not have overt uninterpretable 'go' accompanying silent BE, plausibly because 'be' lends itself to uninterpretability in a way that 'go' cannot.

\section{Conclusion}

Spanish ir ('go') has unexpected $f$-initial forms in the preterite and in the imperfect subjunctive. Rather than being suppletive forms of ir they are forms of ser ('be'). The interpretative contribution of 'go' is provided by the presence of a silent GO. The syntax of silent verbs turns out to be of importance to what appear to be traditional questions of morphology.

\section{References}

Baker, M.C. 2003. Lexical Categories. Verbs, Nouns, and Adjectives. Cambridge: Cambridge University Press. https://doi.org/10.1017/cbo9780511615047

Barbiers, S. 1995. The Syntax of Interpretation. Ph.D. thesis, Holland Institute of Generative Linguistics.

Bergstra, M. 2019. "Micro-variation, contact and change: the absentive in Frisian and Dutch". Handout of a talk given at Utrecht University.

Charnavel, I. 2008. "L'alternance avoir été/être eu dans les auxiliaires du passé surcomposé en français: un nouvel argument pour le caractère syntaxique du morphème se". Proceedings of the 2008 annual conference of the Canadian Linguistics Association.

Collins, C. 2007. "Home Sweet Home". NYU Working Papers in Linguistics 1: 134.

Den Dikken, M. 2010. "Directions from the GET-GO. On the syntax of mannerof-motion verbs in directional constructions," Catalan Journal of Linguistics 9: 23-53. https://doi.org/10.5565/rev/catj1.93

Embick, D. 2003. "Locality, Listedness and Morphological Identity". Studia Linguistica 57: 143-169. https://doi.org/10.1111/j.0039-3193.2003.00102.x

Gallego, Á.J. \& J. Uriagereka 2016. “Estar = Ser + X”. Borealis: An International Journal of Hispanic Linguistics 5: 123-156. https://doi.org/10.7557/1.5.1.3634

Giorgi, A. and F. Pianesi 1997. Tense and Aspect. From Semantics to Morphosyntax. New York: Oxford University Press.

Harris, J. 1993. "The Grammar of Irish English". In J. Milroy \& L. Milroy (eds.), Real English. The Grammar of English Dialects in the British Isles, 139186. London: Longman. https://doi.org/10.4324/9781315845135

Harris, J.W. 1969. Spanish Phonology. Cambridge (MA): MIT Press.

Huddleston, R., J. Payne \& P. Peterson 2002. "Coordination and Supplementation," in R. Huddleston \& G.K. Pullum (eds.), The 
Cambridge Grammar of the English Language, 1273-1362. Cambridge: Cambridge University Press. https://doi.org/10.1017/9781316423530.016

Huddleston, R. 2002. "The Verb". In R. Huddleston \& G.K. Pullum (eds.). The Cambridge Grammar of the English Language, 71-212. Cambridge: Cambridge University Press. https://doi.org/10.1017/9781316423530.004

Kayne, R.S. 2017. "English One and Ones as Complex Determiners". In G. Sengupta, S. Sircar, M.G. Raman \& R. Balusu (eds.), Perspectives on the Architecture and Acquisition of Syntax. Essays in Honor of R. Amritavalli, 77-114. Singapore: Springer Nature. Reprinted in Kayne, R.S. 2019. Questions of Syntax. New York: Oxford University Press. https://doi.org/10.1007/978-981-10-4295-9_4

Kayne, R.S. 2019a. "What is Suppletion? On *goed and on went in Modern English". Transactions of the Philological Society 117: 434-454. https://doi.org/10.1111/1467-968x.12173

Kayne, R.S. 2019b. "The Unicity of There and the Definiteness Effect". In E. Gonçalves (ed.). Existential Constructions in Focus. Brazil: Editora da Universidade Federal da Bahia. Reprinted in Kayne, R.S. 2019. Questions of Syntax. New York: Oxford University Press.

Lockwood, W.B. 1977. An Introduction to Modern Faroese. Tórshavn: Foroya Skúlabókagrunnar.

Marušič, F. \& R. Žaucer. 2005. "On Phonologically Null Verbs. GO and Beyond". Proceedings of ConSOLE XIII.

McShane, M.J. 2000. "Verbal Ellipsis in Russian, Polish and Czech". Slavic and East European Journal 44: 195-233. https://doi.org/10.2307/309950

Mittwoch, A., R. Huddleston \& P. Collins 2002. "The Clause: Adjuncts". In R. Huddleston \& G.K. Pullum (eds.). The Cambridge Grammar of the English Language, 663-784. Cambridge: Cambridge University Press. https://doi.org/10.1017/9781316423530.009

Myler, N. 2018. "Complex copula systems as suppletive allomorphy”. Glossa: a journal of general linguistics 31: 1-43. https://doi.org/10.5334/gjgl.214

Noonan, M. 2010. “'À To Zu””. In G. Cinque \& L. Rizzi (eds.). Mapping Spatial PPs. The Cartography of Syntactic Structures, Volume 6, 161- 195. New York: Oxford University Press.

Pensado, C. 1999. "Morfología y fonología. Fenómenos morfofonológicos". In I. Bosque \& V. Demonte (eds.). Gramática Descriptiva de la Lengua Española, 4423-4504. Madrid: Espasa.

https://doi.org/10.4312/linguistica.41.1.176-178

Pollock, J.-Y. 2006. "Subject Clitics and Complex Inversion" In M. Everaert \& H. van Riemsdijk (eds.). The Blackwell Companion to Syntax, Volume IV, 601-659. Oxford: Blackwell. https://doi.org/10.1002/9780470996591.ch67

Postma, G. 1993. "The Syntax of the Morphological Defectivity of BE". HIL Manuscripts 3: 31-67. 
Roca, I. 2010. "Theme vowel allomorphy in Spanish verb inflection: An autosegmental optimality account". Lingua 120:408-434. https://doi.org/10.1016/j.lingua.2009.05.005

Stockwell, R.P., J.D. Bowen \& J.W. Martin 1965. The Grammatical Structures of English and Spanish. Chicago: The University of Chicago Press. https://doi.org/10.1017/s0022226700001821

van Riemsdijk, H. 2002. "The Unbearable Lightness of Going. The Projection Parameter as a Pure Parameter Governing the Distribution of Elliptic Motion Verbs in Germanic". Journal of Comparative Germanic Linguistics 5: 143-196. https://doi.org/10.1023/a:1021251312697

van Riemsdijk, H. 2003. "Some Thoughts on Specified Ellipsis". In L.-O. Delsing et al. (eds.). Grammar in Focus. Festschrift for Christer Platzack. Volume 2, 257-263. Lund: Wallin \& Dalholm.

vanden Wyngaerd, G.J. 1994. PRO-legomena. Distribution and Reference of Infinitival Subjects. Berlin: Mouton de Gruyter.

Wolfram, W. 2004. "The grammar of urban African American Vernacular English". In B. Kortmann \& E. Schneider (eds.), Handbook of Varieties of English, 111-132. Berlin: Mouton de Gruyter. 